\title{
Pengaruh Food Quality, Restaurant Atmosphere, Price Terhadap Customer Satisfaction dan Implikasinya Terhadap Customer Loyalty Pada Restoran di Kawasan Puncak, Kabupaten Bogor
}

\author{
I Gusti Agung Wahyu Adrian*1, Edwin Adriansyah², Dendy Sundayana3, \\ Mohammad Ridwan ${ }^{4}$, Linandar Tanuwijaya ${ }^{5}$ \\ Sekolah Tinggi Pariwisata Bandung \\ Email: iga_wahyu@stp-bandung.ac.id
}

\begin{abstract}
Penelitian ini merupakan penelitian mengenai bagaimana melihat permasalahan pada restoran di Kabupaten Bogor untuk mencapai suatu kepuasan pelanggan serta terciptanya suatu Customer Loyalty dilihat dari berbagai aspek yaitu, 1). Kualitas makanan, 2). Variasi makanan, 3). Variasi minuman, 4). Kualitas pelayanan, 5). Sikap dan keramahan karyawan, 6). Kualitas suasana, dan 7). Aspek Kebersihan. Komponen - komponen tersebut menjadi pembentuk kepuasan pelanggan yang menjadi fokus penelitian ini. Untuk itu, penelitian ini membahas tingkat pengaruh antara kualitas makanan dan dinescaspe terhadap kepuasan pelanggan Restoran di Kabupaten Bogor. Pengujuan tingkat pengaruh antar komponen tersebut mempunyai tingkat urgensi yang tinggi pada industry restoran mengingat persaingan bisnis di bidang restoran semakin kompetitif dalam memenuhi kebutuhan pengalaman wisatawan di Kabupaten Bogor. Penelitian terdahulu banyak yang melakukan penelitian bagaimana pengaruh makanan, layanan, dan image restaurant terhadap kepuasan seperti peneliti Kisang Ryu, Hyerin Lee, dan Woo Gon Kim (2012), Jay Kandampully, dan Hsin Hui (2007). Pada umumnya kajian - kajian tersebut belum ada yang mengkaitkan secara comprehensive sesuai tema penelitian ini. Penelitian ini termasuk penelitian eksplanatori, yaitu penelitian yang bertujuan menganalisis hubungan-hubungan antara satu variabel dengan variabel lain atau bagaimana suatu mempengaruhi variabel lain. Penelitian ini mengambil populasi data tamu yang peneliti sebarkan kuesionernya selama 5 bulan terakhir yaitu jumlah atau dari periode bulan Agustus -Desember. Jumlah populasi pada penelitian ini berdasarkan data yang diperoleh peneliti adalah 7.954 pelanggan dengan ukuran Sample 381 memakai rumus Slovin.
\end{abstract}

Keywords: Restaurant; Customer Loyalty; Customer Satisfaction.

\begin{abstract}
Abstrak
This research is a research on how to see problems in restaurants in Bogor Regency to achieve customer satisfaction and the creation of a Customer Loyalty seen from various aspects, namely, 1). Quality of food, 2 ). Variety of food, 3). Variations of drinks, 4). Quality of service, 5). Attitudes and friendliness of employees, 6). Quality of atmosphere, and 7). Aspects of Cleanliness. These components form customer satisfaction which is the focus of this research. For this reason, this study discusses the level of influence between food quality and dinescaspe on customer satisfaction in restaurants in Bogor Regency. The level of influence between these components has a high level of urgency in the restaurant industry considering that business competition in the restaurant sector is increasingly competitive in meeting the needs of the tourist experience in Bogor Regency. Many previous studies conducted research on how food, service, and restaurant image influence satisfaction, such as researchers Kisang Ryu, Hyerin Lee, and Woo Gon Kim (2012), Jay Kandampully, and Hsin Hui (2007). In general, none of these studies are related comprehensively according to the theme of this research. This research is an explanatory research, which is research that aims to analyze the relationships between one variable and another or how one affects other variables. This study took a population of guest data that researchers distributed the questionnaire for the last 5 months, namely the number or from the period August-December. The number of population in this study based on the data obtained by the researcher was 7,954 customers with a sample size of 381 using the Slovin formula.
\end{abstract}

Kata Kunci: Restaurant; Customer Loyalty; Customer Satisfaction. 


\section{A. PENDAHULUAN/INTRODUCTION}

Kabupaten Bogor mmerupakan daerah yang memiliki potensi wisata yang sangat beragam. Daya Tarik Wisata (DTW) alam yang terdapat di Kabupaten Bogor adalah Kawasan Puncak yang merupakan Kaki Gunung Gede Pangrango. Kawasan Puncak merupakan kawasan favorit bagi wisatawan asal Jabodetabek (ADP2N Kemenpar, 2017). Posisi Kabupaten Bogor sebagai daerah penyangga kawasan pariwisata Kota Bandung yang dituangkan dalam Peraturan Daerah Nomor 15 Tahun 2015 mengenai Rencana Induk Pariwisata Provinsi Jawa Barat membuat industri restoran harus mempunyai kapasitas yang memadai dalam mendukung kegiatan kepariwisataan Kabupaten Bogor. Saat ini, Jumlah restoran di Kabupaten Bogor yang terdaftar oleh Dinas Pariwisata dan Kebudayaan sebanyak 55 unit.

Dalam persaingan bisnis saat ini yang kompetitif menuntut para pelaku bisnis untuk meningkatkan kualitas di segala bidang. Pada bidang pariwisata khususnya restoran, para pelaku bisnis restoran berlomba - lomba untuk menciptakan produk makanan dan minuman serta suasana pendukung untuk mendapatkan pelanggan.

Faktor kunci dalam mengelola wisatawan yang datang ke suatu daerah adalah pengelolaan pengalaman wisatawan (Middleton, 2001). Industri restoran di Kota Bogor harus mampu dalam mewujudkan pengalaman positif perjalanan wisatawan di Kota Bogor. Indikator utama dalam pengukuran pengalaman wisatawan adalah kepuasan pelanggan (Bitner dan Zeithaml, 2003).

Konsumen restoran memiliki cara masing - masing dalam menikmati makanan untuk memenuhi kebutuhannya. Sebagian dari mereka memilih restoran yang mempunyai pelayanan mewah dengan harapan konsumen akan mencapai kepuasan setelah mengorbankan uang yang besar pada restoran yang mewah tersebut. Pada sisi lain, terdapat konsumen restoran yang mempunyai preferensi untuk menikmati produk makanannya daripada pelayanan yang mewah.

Kepuasan merupakan sebuah perasaan senang atau kecewa yang muncul dari perbandingan tingkat ekspektasi dengan tingkat persepsi (Bitner dan Zeithaml, 2003). Pernyataan tersbut diperkuat oleh peneliti lain yang mengungkapkan bahwa kepuasan pelanggan timbul setelah membandingkan kinerja produk dengan kinerja yang diharapkan (Kotler, 2006, p. 177). Tingkat kepuasan merupakan penilaian terhadap karakteristik dan keistimewaan produk dan jasa yang menyediakan tingkat kesenangan pelanggan terkait pencapaian ekspektasi pelanggan yang diciptakan melalui pelayanan dan komponen pendukung layanan (Lovelock, 2012)

Kondisi aktual dari tingkat kepuasan pelanggan berdasarkan hasil analisis pra survey terhadap konten pada kotak saran menyatakan bahwa dari 147 responden yang membuat saran pada kotak saran di Kabupaten Bogor pada tabel dibawah:

Tabel 1 Analisis Terhadap Konten Kotak Saran Pada Restoran di Kabupaten Bogor

\begin{tabular}{|c|l|c|}
\hline No & \multicolumn{1}{|c|}{ Bahasan } & Presentase \\
\hline 1 & Kualitas makanan & $21,58 \%$ \\
\hline 2 & Variasi makanan & $10,79 \%$ \\
\hline 3 & Variasi minuman & $12,23 \%$ \\
\hline 4 & Kualitas pelayanan & $8,63 \%$ \\
\hline 5 & Sikap dan keramahan karyawan & $10,79 \%$ \\
\hline 6 & Kualitas suasana & $5,76 \%$ \\
\hline 7 & Aspek kebersihan & $20,86 \%$ \\
\hline
\end{tabular}

Sumber: Data Olahan Penelitian, 2018

Berdasarkan tabel tersebut dapat diketahui bahwa kualitas makanan menjadi sorotan utama dengan jumlah responden yang menjawab sebesar 21,58 \%, kemudian disusul aspek kebersihan

2 | Barista: Jurnal Kajian Bahasa dan Pariwisata, Volume 8 Nomor 1, 2021: 
Pengaruh Food Quality, Restaurant Atmosphere, Price Terhadap Customer Satisfaction dan Implikasinya Terhadap Customer Loyalty Pada Restoran di Kawasan Puncak, Kabupaten Bogor

I Gusti Wahyu Adrian, Edwin Adriansyah, Dendy Sundayana, Mohammad Ridwan, Linandar Tanuwijaya.

dengan 20,86 \%. Pernyataan tersebut diperkuat oleh pendapat para ahli yang menyatakan bahwa komponen

pembentuk kepuasan pelanggan dalam bisnis restoran adalah kualitas makanan (Kurniawan, 2015). Berkenaan dengan hal tersebut, Den Hartog dalam (Almatsier, 2002) menyatakan bahwa mayoritas masyarakat memiliki preferensi dalam memilih makanan yang memenuhi selera atau citarasa dalam hal rupa, warna, bau, rasa, suhu serta tekstur makanan. Hal tersbeut diperkuat dengan pernyataan dari West, Wood dan Harger yang menyebutkan bahwa "Quality food standard altough difficult do define and not measurable by mechanical are possible to evaluate interms of the nutritive value, grade of ingredient use, flavor and appearance of the product" (Hersanti, 2012)

Komponen lain dalam pembentuk kepuasan pelanggan dalam bisnis restoran adalah kualitas pelayanan (Putro, 2014) yang terdiri dari komponen tangibles, reliability, responsiveness, assurance dan empathy (Zeinthaml, 2009).

Dalam jurnal lain disebutkan bahwa upaya dinescape atau tampilan fisik pada bisnis restoran mempunyai keterkaitan dalam pembentuk kepuasan pelanggan (Tanjaya, 2015). Dinescape menurut (Ryu, 2005) adalah "the physical environment may be an important determinant of customer satisfaction and subsequent behavior when services are consumed primarily for hedonic purposes and customer spend moderate to log periodes of time in the physical surround".

Lingkungan fisik merupakan salah satu aspek penting kepuasan pelanggan dan perilaku konsumen. Sementara itu menurut (Anggra, 2014) komponen pembentuk dinescape adalah facility aesthetic, ambience, layout dan service product. Pada Tabel 1 diatas dapat dilihat bahwa kualitas suasana serta aspek kebersihan merupakan aspek yang menjadi keluhan pelanggan. Kualitas suasana mempunyai besaran 5,76 \% dari total aspek. Sementara itu, aspek kebersihan mempunyai besaran 20,86 \% dari total keluhan. Aspek - aspek tersebut menurut (Ryu, 2005) merupakan aspek dinescape yang dapat mendorong keterkaitan emosional pelanggan. Pada dasarnya, layout ketiga restoran di Kabupaten Bogor dalam kategori cukup baik dengan desain layout ruang makan yang memperhatikan lalu lintas pengunjung dan pegawai. Akan tetapi facility aesthetic dan ambience ketiga restoran di Kabupaten Bogor dalam kondisi yang kurang apabila dilihat dari kesesuaian tema restoran secara keseluruhan.

Harga merupakan salah satu faktor yang penting serta berpengaruh terhadap tingkat permintaan atas suatu produk, termasuk layanan jasa akomodasi seperti perhotelan. Pada sebagian besar kasus, biasanya permintaan dan harga berbanding terbalik, yakni semakin tinggi harga, semakin rendah permintaan terhadap produk atau jasa. Demikian juga sebaliknya, semakin rendah harga, semakin tinggi permintaan terhadap produk atau jasa. Jika harga yang ditetapkan oleh perusahaan tepat dan sesuai dengan daya beli konsumen, maka pemilihan suatu produk atau jasa tertentu akan dijatuhkan pada produk tersebut. Maka dari itu, penting bagi pengelola hotel dalam menetapkan penetapan harga terhadap produk dan layanan dengan memperhatikan kesesuaian dan kemampuan konsumen.

Kualitas pelayanan merupakan hal yang sangat penting untuk diperhatikan bagi pengelola hotel. Dengan kualitas pelayanan yang baik, hotel akan dapat meningkatkan pangsa pasar dan keuntungan yang optimal. Meningkatkan kualitas layanan dan memuaskan pelanggan merupakan salah satu hal yang menjadi tujuan bagi setiap perusahaan termasuk perusahaan jasa akomodasi. Kualitas pelayanan dibangun atas adanya perbandingan dua faktor utama yaitu persepsi pelanggan atas layanan yang diberikan yang secara nyata mereka terima (perceived service) dengan layanan yang sesungguhnya diharapkan (expected service). Jika pelayanan yang dirasakan pelanggan sesuai dengan yang diharapkan, maka kualitas pelayanan dipersepsikan baik atau memuaskan. Sebaliknya jika pelayanan yang dirasakan lebih kecil dari pada yang diharapkan maka kualitas pelayanan dipersepsikan jelek atau kurang ideal sehingga mereka akan merasa tidak puas. Dengan demikian,

Barista: Jurnal Kajian Bahasa dan Pariwisata, Volume 8 Nomor 1, 2021: 
kualitas pelayanan (service quality) dapat didefinisikan sebagai perbedaan antara kenyataan dan harapan pelanggan atas layanan mereka terima atau peroleh. Pada umumnya kualitas pelayanan yang baik akan dapat menghasilkan kepuasan serta pembelian ulang yang lebih sering dari konsumen (loyalitas). Kepuasan adalah tingkat perasaan seseorang setelah membandingkan kinerja atau hasil yang dia rasakan dibandingkan dengan harapannya. Perasaan puas dan tidak puas seorang pelanggan merupakan respon pelanggan terhadap evaluasi ketidaksesuaian (disconfirmation) yang dirasakan antara harapan sebelumnya dan kinerja aktual produk yang dirasakan setelah pemakaiannya. Oleh karena itu, bagi pengelola usaha penting untuk selalu memperhatikan kualitas pelayanan yang diberikan kepada konsumen agar muncul rasa kepuasan dari konsumen.

Loyalitas dapat diartikan sebagai suatu kesetiaan. Kesetiaan merupakan kondisi yang timbul tanpa adanya paksaan, tetapi timbul dari kesadaran sendiri, tidak dipaksa atau terpaksa. Loyalitas pelanggan merupakan sebuah sikap yang menjadi dorongan perilaku untuk melakukan pembelian produk/jasa dari suatu perusahaan yang menyertakan aspek perasaan didalamnya. Pelanggan yang loyal pada umumnya akan membeli secara teratur dan berulang-ulang dengan konsisten pada produk/jasa yang sama. Selain itu, juga adanya komitmen dan sikap yang positif terhadap perusahaan yang menawarkan produk/jasa tersebut kepada orang lain.

Menurut uraian diatas maka dapat diilustrasikan dinescape memempunyai pengaruh pada tingkat kepuasan pelanggan. Sementara itu, kualitas makanan juga mempunyai pengaruh kepada kepuasan pelanggan. Untuk itu peneliti mempunyai rasa ingin tahu dalam membuktikan tingkat korelasi antara kualitas makanan dan dinescape terhadap kepuasan pelanggan di retoran Kabupaten Bogor. Selain itu, pengujian tingkat pengaruh antara kualitas makanan dan dinescape terhadap kepuasan pelanggan mempunyai tingkat urgensi yang tinggi pada industri restoran mengingat persaingan bisnis di bidang restoran semakin kompetitif dalam memenuhi kebutuhan pengalaman wisatawan pada Kabupaten Bogor.

\section{B. METODE PENELITIAN/RESEARCH METHOD}

Penelitian ini termasuk penelitian eksplanatori, yaitu penelitian yang bertujuan menganalisis hubungan-hubungan antara satu variabel dengan variabel lain atau bagaimana suatu mempengaruhi variabel lain.

Berdasarkan model hubungan kausal sebagaimana dijelaskansebelumnya, maka penelitian ini menggunakan pendekatan kuantitatif dengan disain non eksperimen. Jadi peneliti tidak mengadakan perlakuan terhadap subjek penelitian melainkan mengkaji fakta-fakta yang telah terjadi dan dialami oleh subjek penelitian. Artinya manipulasi terhadap variabel penelitian tidak dilakukan, namun hanya menggali fakta-fakta dari peristiwa yang telah terjadi dengan menggunakan angket yang berisi sejumlah pertanyaan atau pernyataan yang merefleksikan persepsi responden terhadap variabel yang diteliti.

Populasi Dalam penelitian ini, peneliti mengambil populasi berdasarkan data tamu yang peneliti sebarkan kuesionernya selama 5 bulan terakhir yaitu jumlah atau dari periode bulan Agustus -Desember. Jumlah populasi pada penelitian ini berdasarkan data yang diperoleh peneliti adalah 7.954 pelanggan. Dalam menentukan banyaknya sampel, penelitan ini menggunakan teknik slovin dengan taraf kesalahan sebesar 5\% yaitu 381 responden. Teknik analisis dalam penelitian ini menggunakan korelasi product moment, Analisis jalur.

4 | Barista: Jurnal Kajian Bahasa dan Pariwisata, Volume 8 Nomor 1, 2021: 
Pengaruh Food Quality, Restaurant Atmosphere, Price Terhadap Customer Satisfaction dan Implikasinya Terhadap Customer Loyalty Pada Restoran di Kawasan Puncak, Kabupaten Bogor

I Gusti Wahyu Adrian, Edwin Adriansyah, Dendy Sundayana, Mohammad Ridwan, Linandar Tanuwijaya.

\section{HASIL DAN ANALISIS/RESULTS AND ANALYSIS}

Profile demografi responden pada penelitian ini yaitu asal responden yang mayoritas asal berasal dari provinsi Sumatra Selatan sebesar 58,50\% diikuti oleh responden asal Jawa Barat $14,76 \%$, dan paling akhir asal responden dari Jawa Tengah 0,59\%. Kemudian profile usia reseponden didominasi range umur dibawah 20 Tahun sebesar 47,08\%, Pekerjaan responden didominasi oleh para pelajar dan mahasiswa sebesar 273 atau 76,04\%, lalu karyawan swasta sebesar 51 atau 14.21\%. Hasil dari variable dibagi menjadi tiga. 1). Variabel kualitas makanan didapatkan bahwa berdasarkan hasil temuan lapangan a). Penampilan makanan indikator mengetahui penampilan makanan mendapatkan skor 1574 dari 359 responden. Tingkat performansi pada indikator ini adalah sebesar 87,69. Dalam hal ini, performansi indikator tersebut pada kondisi sangat baik; b). Rasa makanan indikator memperhatikan ada atau tidaknya gambar tersebut Rasa Makanan mendapatkan skor 1530 dari 359 responden. Tingkat performansi pada indikator ini adalah sebesar 85,24. Dalam hal ini, performansi indikator tersebut pada kondisi sangat baik; c). Mutu Hidangan, indikator halal pada gambar terlihat jelas mendapatkan skor 1477 dari 359 responden. Tingkat performansi pada indikator ini adalah sebesar 82,28. Dalam hal ini, performansi indikator tersebut pada kondisi sangat baik; d). Kandungan Gizi indikator kandungan gizi membantu mengidentifikasi produk sebelum digunakan mendapatkan skor 1347 dari 359 responden. Tingkat performansi pada indikator ini adalah sebesar 75,04. Dalam hal ini, performansi indikator tersebut pada kondisi cukup baik; e). Suhu makanan Berdasarkan pada hasil diatas, mengetahui suhu makanan mendapatkan skor 1496 dari 359 responden. Tingkat performansi pada indikator ini adalah sebesar 83,34. Dalam hal ini, performansi indikator tersebut pada kondisi sangat baik; f). Memunculkan khas, indikator memunculkan khas mendapatkan skor 1409 dari 359 responden. Tingkat performansi pada indikator ini adalah sebesar 78,50. Dalam hal ini, performansi indikator tersebut pada kondisi sangat baik. 2). Variabel Restaurant Atmosphere ada beberapa indikator pada variabel ini; a). Desain estetika desain estetika mendapatkan skor 1795 dari 359 responden. Tingkat performansi pada indikator ini adalah sebesar 70,31. Dalam hal ini, performansi indikator tersebut pada kondisi baik; b). Suasana Restoran Berdasarkan pada hasil diatas, suasana restaurant mendapatkan skor 1795 dari 359 responden. Tingkat performansi pada indikator ini adalah sebesar 75,49. Dalam hal ini, performansi indikator tersebut pada kondisi cukup baik; c). Tata ruang Restorant tata ruang restaurant mendapatkan skor 1795 dari 359 responden. Tingkat performansi pada indikator ini adalah sebesar 84,01. Dalam hal ini, performansi indikator tersebut pada kondisi sangat baik; d). Cara menyajikan makanan indikator cara menyajikan makanan skor 1795 dari 359 responden. Tingkat performansi pada indikator ini adalah sebesar 77,88. Dalam hal ini, performansi indikator tersebut pada kondisi cukup baik; e). Penampilan karyawan indikator penampilan karyawan mendapatkan skor 1795 dari 359 responden. Tingkat performansi pada indikator ini adalah sebesar 79,55. Dalam hal ini, performansi indikator tersebut pada kondisi cukup baik. 3). Kepuasan pelanggan ada beberapa indikator pada variabel ini; a). Akan berkunjung kembali Berdasarkan pada hasil diatas, indikator akan berkunjung kembali mendapatkan skor 1795 dari 359 responden. Tingkat performansi pada indikator ini adalah sebesar 78,16. Dalam hal ini, performansi indikator tersebut pada kondisi cukup baik; b). Akan merekomendasikan restoran indikator akan merekomendasikan restaurant mendapatkan skor 1795 dari 359 responden. Tingkat performansi pada indikator ini adalah sebesar 70,64. Dalam hal ini, performansi indikator tersebut pada kondisi cukup baik. c). Akan mengingat Restoran indikator akan mengingat restaurant mendapatkan skor 1795 dari 359 responden. Tingkat performansi pada indikator ini adalah sebesar 78,11. Dalam hal ini, performansi indikator tersebut pada kondisi cukup baik; d). Bersedia membayar lebih indikator bersedia membayar lebih mendapatkan skor 1795 dari 359 responden. Tingkat performansi pada indikator ini adalah sebesar 75,21. Dalam hal ini, performansi indikator tersebut pada kondisi cukup baik.

Barista: Jurnal Kajian Bahasa dan Pariwisata, Volume 8 Nomor 1, 2021: 
Uji asumsi klasik dilakukan terbagi jadi tiga bagian yang pertama Uji normalitas, data Uji normalitas bertujuan untuk menguji apakah dalam model regresi, variabel terikat dan variabel bebas keduanya mempunyai distribusi normal atau tidak. Model regresi yang baik adalah yang memiliki distribusi data normal atau mendekati normal. Untuk menguji apakah distribusi data normal atau tidak, salah satu cara melihat normalitas adalah melihat histogram yang membandingkan antara data observasi dengan distribusi yang mendekati distribusi normal (Ghozali, 2005:31). Hasil output SPSS untuk uji normalitas dengan analisis grafik adalah sebagai berikut:

Gambar 1

Uji Normalitas Penelitian

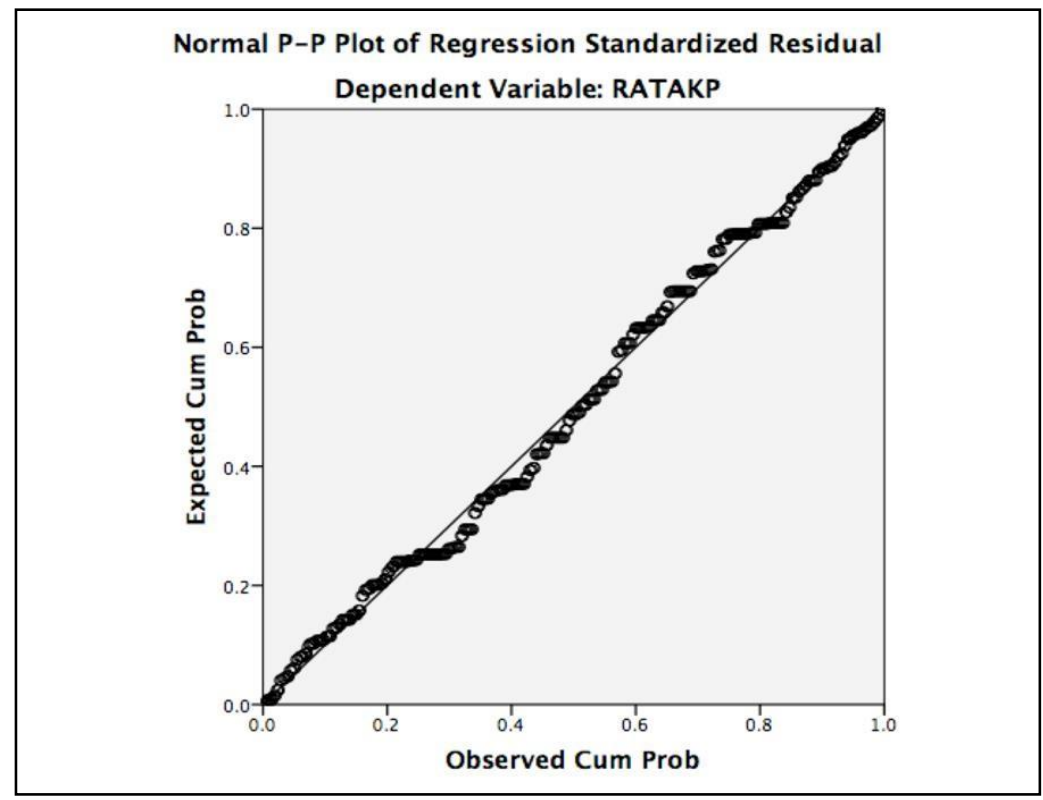

Source: data olahan penelitian

Pada bagian kedua yaitu Uji Multikolinieritas Uji multikolinieritas diperlukan untuk mengetahui ada tidaknya variabel independen yang memiliki kemiripan dengan variabel independen lain dalam satu model.

Tabel 1

Uji Multikolinieritas

\begin{tabular}{|cc|c|c|c|c|c|}
\hline \multirow{2}{*}{ ModeL } & \multicolumn{3}{|c|}{ Correlations } & \multicolumn{2}{c|}{ Collinearity Statistics } \\
\cline { 3 - 7 } & & Zero- & Partial & Part & Tolerance & VIF \\
\hline 1 & X1 & .596 & .329 & .187 & .717 & 1.394 \\
& X2 & .824 & .745 & .599 & .717 & 1.394 \\
\hline
\end{tabular}

Source: data olahan penelitian

Dari Hasil pengujian diperoleh nilai VIF untuk variabel faktor Restaurant Atmosphere dan Harga adalah 1,394 dan nilai trsebut jauh dari 10, dengan demikian dapat disimpulkan tidak ada multikolinieritas, yang ketiga yaitu Uji Heterodaksititas Uji heteroskedastisitas di maksudkan untuk mendeteksi gangguan yang diakibatkan faktor-faktor dalam model regresi tidak memiliki varians

6 | Barista: Jurnal Kajian Bahasa dan Pariwisata, Volume 8 Nomor 1, 2021: 
Pengaruh Food Quality, Restaurant Atmosphere, Price Terhadap Customer Satisfaction dan Implikasinya Terhadap Customer Loyalty Pada Restoran di Kawasan Puncak, Kabupaten Bogor

I Gusti Wahyu Adrian, Edwin Adriansyah, Dendy Sundayana, Mohammad Ridwan, Linandar Tanuwijaya.

yang sama. Jika varians berbeda disebut homoskedastisitas, model regresi yang baik jika tidak terjadi heteroskedastisitas. Pengujian heteroskedasisitas dilakukan dengan menggunakan scatter plot. Jika tidak terdapat pola tertentu menunjukkan bahwa model regresi tersebut bebas dari masalah heteroskedastisitas. Adapun grafik hasil ujicoba heteroskedastisitas adalah sebagai berikut

Gambar 2

Uji Hetrodaksititas

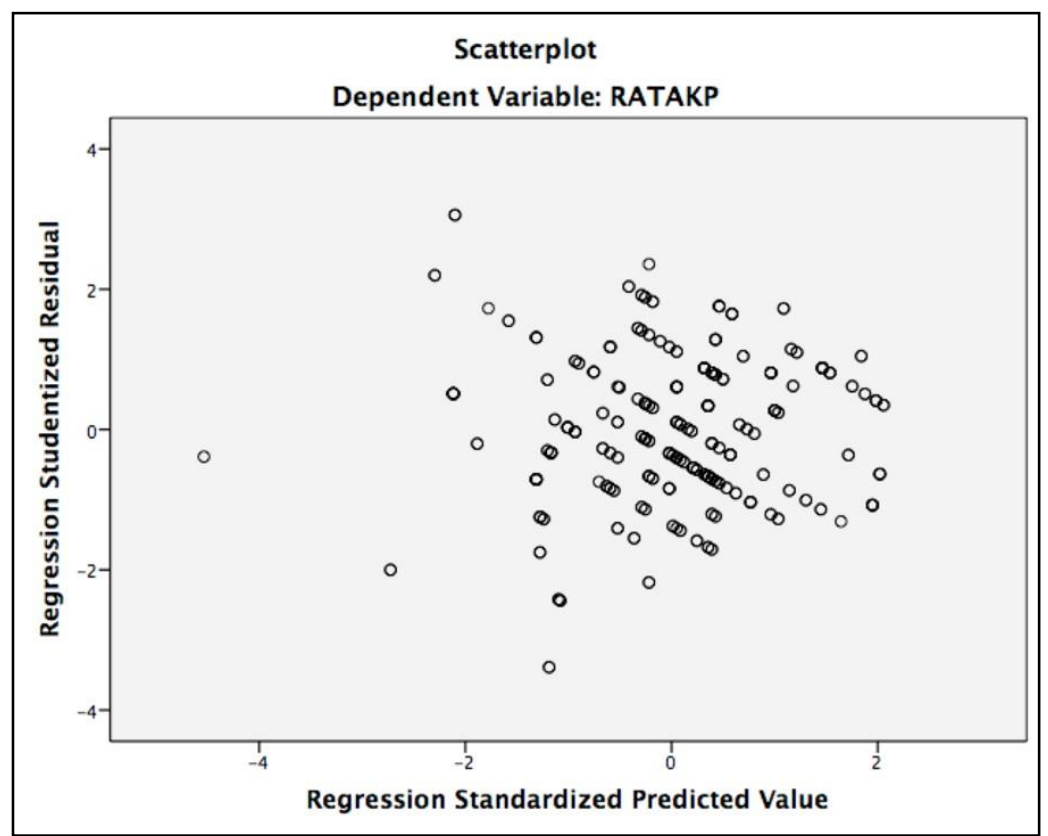

Source: data olahan penelitian

Gambar tersebut menunjukkan bahwa titik-titik yang menyebar secara acak, tidak membentuk pola tertentu serta tersebar baik di atas maupun di bawah angka 0 (nol) pada sumbu $Y$, dengan demikian maka dapat dinyatakan bahwa data tersebut bebas dari gejala heteroskedastisitas.

Uji Signifikansi salah satu juga sebagai pengujian yang dilakukan pada penelitian ini a). Pengujian koefisien pengaruh variabel kualitas makanan (XI) terhadap kepuasan pelanggan (Y).

Tabel 2

Pengujian Signifikansi X1 Terhadap Y

\begin{tabular}{|c|c|c|c|c|c|}
\hline Koefisien Korelasi & $\begin{array}{c}\text { Koefisien } \\
\text { Jalur }\end{array}$ & $\mathrm{t}$ hitung & $\mathrm{t}$ tabel & Keterangan & Total Pengaruh \\
\hline 0,682 & 0,551 & 6,154 & 1,983 & Signifikan & 0,509 \\
\hline
\end{tabular}

Sumber: Data Olahan Penelitian

Tabel di atas menunjukkan bahwa koofesien (r) antara variabel Kualitas Makanan (X1) dan Kepuasan Pelanggan (Y) adalah sebesar 0,682 artinya terdapat adanya hubungan yang erat antara variabel Kualitas Makanan (X1) dan Kepuasan Pelanggan (Y). Selanjutnya melalui uji signifikansi atas dasar koefisien jalur antara kedua variabel tersebut yaitu PX1Y = 0,551 nampak bahwa t hitung = 6,154 lebih besar dari t tabel = 1,983. Ini berarti pengaruh variabel Kualitas Makanan (X1) terhadap Kepuasan Pelanggan (Y) adalah sangat signifikan. Dengan demikian secara empirik, Kualitas Makanan berpengaruh positif dan signifikan terhadap peningkatan Kepuasan Pelanggan di Topas 
Galeri Hotel Bandung. b). Pengujian koefisien pengaruh variabel restoran atmosphere (X2) terhadap kepusan pelanggan $(\mathrm{Y})$.

Tabel 3

Pengujian Signifikansi X1 Terhadap Y

\begin{tabular}{|c|c|c|c|c|c|}
\hline $\begin{array}{c}\text { Koefisien } \\
\text { Korelasi }\end{array}$ & $\begin{array}{c}\text { Koefisien } \\
\text { Jalur }\end{array}$ & thitung & $\mathrm{t}$ tabel & Keterangan & Total Pengaruh \\
\hline 0,773 & 0,561 & 4,443 & 1,983 & Signifikan & 0,857 \\
\hline
\end{tabular}

Sumber: Data Olahan Penelitian

Tabel di atas menunjukkan bahwa koofesien (r) antara variabel Kualitas Makanan (X1) dan Restaurant Atmosphere (X2) terhadap Kepuasan Pelanggan (Y) adalah sebesar 0,773 artinya terdapat adanya hubungan yang erat antara variabel Kualitas Makanan (X1) dan Restaurant Atmosphere (X2) terhadap Kepuasan Pelanggan (Y). Selanjutnya melalui uji signifikansi atas dasar koefisien jalur antara kedua variabel tersebut yaitu PYX1X2 $=0,561$ nampak bahwa thitung $=4,443$ lebih besar dari t tabel = 1,983. Ini berarti pengaruh variabel Kualitas Makanan (X1) dan Restaurant Atmosphere (X2) terhadap Kepuasan Pelanggan (Y) adalah positif dan signifikan.

Dengan demikian secara empirik dapat dikatakan bahwa Kualitas Makanan dan Restaurant Atmosphere berpengaruh positif dan signifikan terhadap Kepuasan Pelanggan. Hal ini dapat dibuktikan dengan adanya peningkatan Kepuasan Pelanggan yang memiliki motivasi dalam bekerja dan guru yang profesional meskipun relatif kecil, dimana hal tersebut mencakup: pengetahuan dan ketrampilan guru untuk bekerja secara kreatif, inovatif, produktif, efektif dan efisien sesuai Standar Operasional Prosedur yang telah ditetapkan sekolah.

Melihat dari besarnya pengaruh diatas, dan berdasarkan pengamatan serta hasil wawancara dengan sebagian responden ternyata Kualitas Makanan dan Restaurant Atmosphere belum optimal dalam meningkatkan Kepuasan Pelanggan.

\section{SIMPULAN/CONCLUSION}

Simpulan dari penelitian ini yaitu bagaimana pengaruh dari kualitas makanan (X1) sebesar 0,551 terhadap kepuasan pelanggan (Y). kemudian Restaurant Atmosphere (X2) sebesar 0,637 terhadap kepuasan pelanggan (Y). kemudian X1 dan X2 sebesar 0,382. Adapun perhitungan table tersebut sebagai berikut:

Tabel 4

Pengaruh Kualitas Makanan

\begin{tabular}{|c|c|c|}
\hline Langsung & $0,551^{2}$ & $30,36 \%$ \\
\hline Melalui $\mathrm{x} 2$ & $0,509 \times 0,382 \times 0,551$ & $10,71 \%$ \\
\hline Total & & $42,07 \%$ \\
\hline
\end{tabular}

Tabel 5

Pengaruh Restaurant Atmosphere

8 | Barista: Jurnal Kajian Bahasa dan Pariwisata, Volume 8 Nomor 1, 2021: 
Pengaruh Food Quality, Restaurant Atmosphere, Price Terhadap Customer Satisfaction dan Implikasinya Terhadap Customer Loyalty Pada Restoran di Kawasan Puncak, Kabupaten Bogor

I Gusti Wahyu Adrian, Edwin Adriansyah, Dendy Sundayana, Mohammad Ridwan, Linandar Tanuwijaya.

\begin{tabular}{|c|c|c|}
\hline Langsung & $0,637^{2}$ & $40,57 \%$ \\
\hline Melalui $x 1$ & $0,551 \times 0,382 \times 0,637$ & $13,41 \%$ \\
\hline Total & & $53,98 \%$ \\
\hline
\end{tabular}

Pengaruh secara simultan dari kedua variabel terhadap kepuasan pelanggan adalah pengaruh kualitas makanan 42,07\%, pengaruh restaurant atmosphere 53,98\%, simultante (jumlah pengaruh) $\mathrm{R}^{2} 95,05 \%$, dan pengaruh lain 4,95\%.

Tabel 5

Simpulan Pengaruh

\begin{tabular}{|c|c|c|c|c|c|}
\hline \multirow[t]{2}{*}{ No } & \multirow[t]{2}{*}{ Variabel } & \multirow[t]{2}{*}{ Langsung } & $\begin{array}{c}\text { Tidak } \\
\text { Langsung }\end{array}$ & & $\begin{array}{c}\text { Pengaruh } \\
\text { Total }\end{array}$ \\
\hline & & & $\mathrm{X} 1$ & $\mathrm{X} 2$ & \\
\hline 1 & Kualitas Makanan & 0,551 & - & 0,382 & $42,07 \%$ \\
\hline 2 & $\begin{array}{l}\text { Restaurant } \\
\text { Atmosphere }\end{array}$ & 0,637 & 0,382 & - & $53,98 \%$ \\
\hline \multicolumn{2}{|c|}{ Simultan } & & \multicolumn{2}{|c|}{$95,05 \%$} & \\
\hline
\end{tabular}

Dapat disimpulkan bahwa pengaruh daripada kualitas makanan dan restaurant atmosphere sangat mempengaruhi kepuasan pelanggan dalam melakukan aktivitas yang berpengalaman. Serta bagaimana dari kepuasan tersebut akan tercipta suatu prilaku konsumen atau wisatawan yang makan menjadi suatu loyalty customer yang menjadi asset perusahaan atau restaurant tersebut.

\section{DAFTAR REFERENSI/REFERENCES}

Kotler dan Amstrong. (2012). Prinsip - Prinsip Pemasaran. Jakarta: Erlangga. 
Jang. (2007). Does Food Quality Really Matter in Restaurants? Its Impact on Customers Statisfaction and Behavioral Intention. Jurnal of Hospitaly and Tourism Research, 1-17.

Sparks, B. (2015). Retaurant As A Contributor To Tourist Destination Attractiveness. Journal of CRC for Sustainable Tourism, 1-21.

Wilianto, V. (2012). Pengaruh Physical Environment Terhadap Customer Satisfaction Yang Membentuk Behavioral Intention Di Domi Deli Restaurant Surabaya : Aplikasi Skala Pengurkuran Dinescape. Jurnal Universitas Petra, 72-78.

Edith, I. N. (2012). Food Quality Control. Journal Of Agricultural, 422-435. Margaretha. (2012). Analisa Pengaruh Food Quality \& Brand Image terhadap Keputusan Pembeli Roti KEcik Toko Roti Ganep's Di Kota Solo. Manajemen Pemasaran, 34-52.

Al-Tit, A. (2015). The Effect of Service and Food Quality on Customer Satisfaction and Hence Customer Retention . Journal Of Business Administration Department, College of Business \& Economics (CBE), Qassim University, 129- 139.

Fadhilah, S. N. (2015). The Influence of Service Quality and Food Quality Towards Customer Fulfillment and Revisit Intention. Journal Of Social Science CS Canada, 110-116.

Almohaimmeed, B. M. (2017). Restaurant Quality and Customer Satisfaction. International Review of Management and Marketing, 42-49.

Rozekhi, N. A. (2016). The Influence of Food Quality on Customer Satisfaction in Fine Dining Restaurant: Case in Penang. International Academic ResearchJournal of Business and Technology, 45-50.

Mohaydin, G. (2017). Effect of Food Quality on Customer Perceived Satisfaction Level and Mediating Effect of Food Safety on Them. International Journal of New Technology and Research, 34-41.

Marthianus, J. (2015). Pengaruh Restoran Atmosfer, Kualitas Makanan Dan Kualitas Layanan Terhadap Perveived Value Konsumen Restoran De Soematra, Surabaya. Jurnal Manajemen Perhotelan, Universitas Kristen Petra, 200-216. Ismoyo, D. D. (2010). Pengaruh Variasi Menu dan Citarasa Makanan Buffet Dinner Terhadap Keupasan Tamu Restoran Gris Di Crowne Plaza Semarang. Jurnal Gemawisata, 66-73.

Evirasanti, M. (2016). Pengaruh Kualitas Makanan, Kualitas Layanan dan Lingkungan Fisik Terhadap Kepuasan Dan Behavioural Intentions. E-Jurnal Ekonomi dan Bisnis Universitas Udayana, 43314358.

Tanuwidjaja, G. (2015). Persepsi Mahasiswa Terhadap Atmosfer Tempat Makan Yang Menggugah Selera Terhadap Makanan Tradisional. Jurnal Arsitektur Universitas Petra, 29-36.

Dahmer, S. (2009). Restaurant Service Basics. New Jersey: John Wiley \& Sons, Inc. Sukmana, Y. (2017, 10

17). 3 Tahun Jokowi-JK, Pariwisata Sumbang Devisa Terbesar Kedua. Retrieved 01 19, 2018,

From ekonomi.kompas.com: https://ekonomi.kompas.com/read/2017/10/17/220236426/3 tahun-jokowi-jk- pariwisata-sumbang-devisa-terbesar-kedua

Wahab, S. (2003). Manajemen Kepariwisataan. Jakarta: PT Pradana Paramita.

Pitana, I. G. (2005). Sosiologi Pariwisata, Kajian Sosiologis Terhadap Struktur, Sistem dan Dampak-dampak Pariwisata. Yogyakarta: Ando Offset.

Puspitasari, S. (2011). Potensi Wisata Agro Kabupaten Bandung Berdasarkan Aspek Permintaan dan

Penawaran. Jurnal Perencanaan Wilayah dan Kota, 33-48. ADP2N Kemenpar. (2017). Analisis

Pasar WIsatawan Nusantara Tahun 2017. Jakarta: Kementerian Pariwisata Republik Indonesia.

Middleton, V. (2001). Marketing in Travel and Tourism 3rd Edition. Bodmin: MPG Books Ltd.

Bitner dan Zeithaml. (2003). Service Marketing. New Delhi: McGraw Hill.

Kotler. (2006). Manajemen Pemasaran Jilid I Edisi Kesebelas. Jakarta: PT Indeks Gramedia.

Lovelock, C. (2012). Manajemen Pemasaran dan Pemasaran Jasa. Jakarta: Erlangga. Kurniawan, E. (2015). 
Pengaruh Food Quality, Restaurant Atmosphere, Price Terhadap Customer Satisfaction dan Implikasinya Terhadap Customer Loyalty Pada Restoran di Kawasan Puncak, Kabupaten Bogor

I Gusti Wahyu Adrian, Edwin Adriansyah, Dendy Sundayana, Mohammad Ridwan, Linandar Tanuwijaya.

Pengaruh Kualitas Makanan dan Kualitas Layanan Pada Kepasan Dan Loyalitas Konsumen Restoran Korea "Myoung Ga" Di Surabaya Dengan Peran Moderasi Atmosfer. Jurnal Ilmiah Mahasiswa Universitas Surabaya, 12-23.

Almatsier, S. (2002). Prinsip Dasar Ilmu Gizi. Jakarta: Gramedia Pustaka Jakarta. Hersanti, N. J. (2012). Pengaruh Atmosfer Terhadap Kepuasan dan Niatan Perlikau KOnsumen di Toko Oen Kota Malang. Jurnal Aplikasi Manajemen, 10, 773- 780.

Putro, S. W. (2014). Pengaruh Kualitas Layanan Dan Kualitas Produk Terhadap Kepuasan Pelanggan Dan Loyalitas Konsumen Restoran Happy Garden Surabaya. Jurnal Manajemen Pemasaran, 1-9.

Zeinthaml, V. (2009). Service Marketing 5Th Edition. Singapore: The McGraw-Hill Companies, Inc. Tanjaya, S. C. (2015). Analisis Pengaruh Kualitas Makanan, Pelayanan dan Lingkungan Fisik Terhadap Kepuasan Pelanggan Studi Kasus Pada Cabal Dining. Jurnal Berkala Ilmiah Efisiensi, 99-108.

Ryu, K. (2005). Dinescape, Emotions and Behavioral Intentions In Upscale Restaurants. Journal Doctor Of Philosophy, 166-179. Anggra, D. (2014). Analisa Pengaruh Lingkungan Fisik Terhadap Niat Berperilaku Melalui Emosi Konsumen Di Domicile Kitchen and Lounge Surabaya. Jurnal Manajemen Perhotelan, 112-123. 